\title{
Capture of enzyme aggregates by covalent immobilization on solid supports. Relevant stabilization of enzymes by aggregation.
}

\author{
Paz García-García a, Gloria Fernandez-Lorente ${ }^{a,}{ }^{*}$, Jose M. Guisan ${ }^{b, *}$. \\ a Laboratory of Microbiology and Food Biocatalysis. Institute of Food Science Research \\ (CIAL, CSIC-UAM). Nicolás Cabrera, 9. UAM Campus, Cantoblanco. 28049, Madrid, Spain \\ ${ }^{b}$ Department of Biocatalysis, Institute of Catalysis and Petrochemistry (ICP, CSIC). Marie \\ Curie, 2. UAM Campus, Cantoblanco. 28049, Madrid, Spain
}

* Corresponding authors. e-mail address: jmguisan@icp.csic.es; g.f.lorente@csic.es

\section{HIGHLIGHTS}

- Amino oxidase of P. sativum (AO) was stabilized ( 200 fold) by immobilization tools

- $30 \%$ PEG promotes the formation of soluble bimolecular enzyme aggregates

- The aggregate is i§fixedi“ by multipoint covalent immobilization $(\mathrm{MCl})$ on solid supports

- Enzyme aggregation protects $\mathrm{AO}$ from distortions promoted by $\mathrm{MCl}$

- Enzyme aggregation promotes a 40 fold increase of thermal stability of AO

\begin{abstract}
In this paper, a novel procedure for the immobilization and stabilization of enzymes is proposed: the multipoint covalent attachment of bi-molecular enzyme aggregates. This immobilization protocol allows the "capture" and fixation of the enzyme aggregate on the support surface. In addition to stabilization by multipoint attachment, enzyme aggregation promotes very interesting stabilizing effects. In the presence of low concentrations of polyethylene glycol (30\%) the dimeric amine oxidase from Pisum sativum forms soluble bi-molecular aggregates. Enzyme aggregates were analyzed by Dynamic Light Scattering and by full chemical loading of a mesoporous support (10\% agarose gels activated with glyoxyl groups). The soluble aggregate was immobilized by multipoint attachment on glyoxyl- agarose at $\mathrm{pH} 8.5$ though the four amino termini of the two dimeric molecules (Lys residues are not reactive at this $\mathrm{pH}$ ). The immobilized aggregated structure cannot undergo any movement (translational or rotational) after multipoint attachment and the aggregate is "fixed" on the support surface even after the removal of PEG. The immobilized aggregate was further incubated at $\mathrm{pH} 10$ in order to allow the Lys residues to react with the glyoxyl groups on the support. Enzyme aggregation has an important effect on enzyme stabilization: the aggregated derivative was 40 fold more stable than a similar derivative of the isolated enzyme and 200 fold more than native enzymes in experiments of thermal inactivation.
\end{abstract}

Keywords: enzyme stabilization; bi-molecular aggregates; multipoint covalent immobilization

\section{Introduction}


processes, it is important to develop strategies of enzyme stabilization using immobilization techniques. These procedures allow, in a unique step, the preparation of very stable heterogeneous biocatalysts (Guisan, 2013; Jemli et al., 2016; Prasad and Roy, 2017).

One of the main protocols for the immobilization and stabilization of enzymesare multipoint covalent attachment on highly activated supports.

Multipoint covalent attachment promotes an interesting stabilization of industrial enzymes (Singh et al., 2013), where the relative positions of every residue of the enzyme involved in the attachment to the support must stay invariable during any conformational change. In this way, distorting agents such as heat or solvents will provoke less intense changes (Mateo et al., 2007. Fernandez-Lorenteetal., 2015; H. Orregoetal., 2018; Mateo et al., 2005). Therefore, stabilizations of more than 100 industrial enzymes can be achieved with stabilization factors of around 1000 times (Fernández-Lorente et al., 2015; Terrasan et al., 2016; Trobo-Maseda et al., 2018).

In this work, a novel strategy for the immobilization and stabilization of enzymes is proposed. This new protocol involved the multipoint covalent immobilization of bi-molecular enzyme aggregates in the presence of moderate concentrations of PEG. The synergistic effect of both protocols on the stabilization of multimericenzymes was studied.

After aggregate formation in the presence of PEG, multipoint covalent immobilization was carried out involving the two aggregated molecules. These molecules in the aggregate can not undergo any further movement even when PEG is removed. In this way, the close contact between immobilized molecules at very high local concentration should become associated in a very similar way to those of soluble enzymes in the presence of PEG. Thus, multi-point immobilization of enzymatic aggregates may promote the capture and fixation of immobilized aggregates.

Thus, the application of this new protocol was studied using amine oxidase (AO) from Pisum 
sativum, a dimeric extracellular enzyme with $120 \mathrm{kDa}$ molecular weight (see scheme 1 ) (McGuirl et al., 1994; Yagodina et al., 2002). The stability of this enzyme has to be greatly improved (atacidicpH or in the presence of ethanol) due to its applicationsfor the degradation of the biogenicamines present in wine (Callejón et al., 2016; García-Ruiz et al., 2011).

Recently, our group achieved the immobilization of this dimeric enzyme by simultaneous covalent attachment of both amino-termini on a highly activated glyoxyl-agarose support at pH 8.5 (Garcia-Garcia et al., 2019). This orientation of the immobilized enzyme permits the stabilization of the quaternary structure as a result of the immobilization process (Marqués et al., 2011.; Orrego et al., 2017). Furthermore, additional covalent attachment between the enzyme and support was developed by additional incubation at $\mathrm{pH} 10$ where Lys residues become reactive. However, while immobilization at this orientation seems to be very promising, immobilization rate, recovered activity, and stability need to be improved. For this reason, optimization of the process was studied in this paper.

Immobilization of AO in the presence of small amounts of PEG was studied by promoting aggregation processes (e.g., the formation of a bi-molecular aggregate) in order to explore and optimize all the parameters for immobilization and stabilization of this interesting industrial enzyme. Differences in terms of activity and stability between immobilized aggregates and the immobilized isolated enzyme could provide knowledge about the effects of aggregation on the 3D stabilization of the enzyme.

The approximate size of the enzymatic aggregates generated in the presence of different concentrations of PEG was qualitatively measured by Dynamic Light Scattering (DLS). On the other hand, the quantitative determination of the molecular weight of the aggregates was achieved by studying the immobilization rate and enzyme loading on $10 \%$ agarose, which is a mesoporous support with an exclusion limit of $500 \mathrm{kDa}$ for proteins. The quantitative size of the enzyme aggregate was calculated by measuring 
the maximal amount of aggregate immobilized on activated $10 \%$ agarose gel (a mesoporous support with an exclusion limit of $500 \mathrm{kDa}$ proteins). Up to $200 \mathrm{mg}$ of proteins (with MW up to $250 \mathrm{kDa}$ ) per gram of support can be immobilized on this mesoporous support. If the proteins were larger the loading capacity will be much lower. The immobilization of very large proteins in the outer part of the porous structure of the support reduces the "effective" pore size and the complete loading of the porous support becomes impossible.

It seems that bi-molecular enzymatic aggregates, which were obtained in the presence of $30 \%$ of PEG could be immobilized on the support via a bimolecular attachment. These derivatives were very active and highly stabilized. Additionally, immobilization of the enzyme through the amino termini allows the region with the highest density of lysine residues to remain unaltered, thus permitting further stabilization protocols with polymers (Moreno-Pérez et al., 2016).

\section{Materials and Methods}

\subsection{Materials}

1,4-Diaminobutane (putrescine), o-phenilendiamine (OPD), peroxidase type I from horseradish, sodium borohydride, glycidol (2,3-epoxy propanol), polyethylene glycol $6000 \mathrm{Da}$, and other reagents of common use were acquired from Sigma (St. Louis, USA). Diamine oxidase from Pisum sativum (DiaMaze, AO) was kindly donated by Bio-Research Products (North Liberty, USA). The glyoxyl-agarose $6 \mathrm{BCL}$ ( $6 \%$ and $10 \%$ beads crosslinked) support was provided by Agarose Beads Technology (ABT) (Madrid, Spain) and the cyanogen bromide-activated Sepharose 4B support was purchased from GE Healthcare (Madrid, Spain).

\subsection{Determination of Amine Oxidase Activity}


Amine oxidases catalyze the oxidation of biogenic amines producing aldehydes, ammonia and hydrogen peroxide. The latter by-product was used in a coupled reaction between amine oxidase and peroxidase to spectrophotometrically measure the enzymatic activity of AO. When the biogenic amine is oxidized by the action of the AO, the peroxidase decomposes the hydroxide peroxide using o-phenylenediamine (OPD) as a substrate, producing a colorimetric compound. This compound results in an increase of the absorbance at $450 \mathrm{~nm}$. Thus, the relationship between the production of the colorimetric compound and the decomposition of biogenic amines is proportional.

Amine oxidase activities of soluble and immobilized enzymes were spectrophotometrically measured at $450 \mathrm{~nm}\left(\varepsilon=16.3 \mathrm{mM}^{-1} \mathrm{~cm}^{-1}\right)$ (Fernandez-Lafuente et al., 1999), by monitoring the decomposition of biogenic amines (BA). The reaction mixture composed of $0.3 \mathrm{~mL}$ of $50 \mathrm{mM}$ putrescine, $0.1 \mathrm{~mL}$ of $18.5 \mathrm{mM}$ OPD, and $0.1 \mathrm{~mL}$ peroxidase of $1 \mathrm{mg} / \mathrm{mL}$, in $1.85 \mathrm{~mL}$ of $50 \mathrm{mM}$ sodium phosphate buffer at $\mathrm{pH}$ 6.0. The reaction was initiated by adding $0.1 \mathrm{~mL}$ of enzyme solution. One amine oxidase unit is defined as the amount of enzyme that catalyzes the decomposition of $1 \mu \mathrm{mol}$ of putrescine per minute (International Units) under the conditions described. All measurements were carried out at $25 \circ \mathrm{C}$ with magnetic agitation (UV-Vis Jasco Model V630).

\subsection{Dynamic Light Scattering (DLS) Analysis}

DLS measurements were performed with a Malvern Zetasizer Nano ZS (Malvern, Herrenberg, Germany) equipped with a 633-nm He-Ne laser and operating at an angle of $173^{\circ}$. The software used to collect and analyze the data was the Dispersion Technology Software version 6.01 from Malvern.

At least 1-2 $\mathrm{mL}$ of sample were prepared in order to obtain good quality data. Different solutions of amine oxidase prepared in the presence of $10 \%, 30 \%$, and $50 \%$ PEG in 50 
$\mathrm{mM}$ sodium phosphate buffer $\mathrm{pH} 7.0$ were analyzed and compared with amine oxidase dissolved in phosphate buffer in the absence of PEG.

\subsection{Preparation of immobilization Supports}

The agarose matrix was activated with glycidol and subsequent oxidation was activated with periodate, following the literature (Guisan, 1988). This process results in glyoxylagarose supports with aldehyde groups, which are the reactive groups in the support.

The cyanogen bromide support $(\mathrm{CNBr})$ was prepared according to the supplier's instructions. A total of $0.3 \mathrm{~g}$ of support was activated by hydrating the sample with 20 $\mathrm{mL}$ of distilled water. The $\mathrm{pH}$ was decreased to $2.0-2.5$ with hydrochloric acid solution. It was stirred for 30 minutes, filtered without washing, and dried by suction.

\subsection{Enzyme Immobilization of Pisum sativum Amine Oxidase by Single Point Covalent}

\section{Attachment on Cyanogen Bromide Supports}

A total of $2.5 \mathrm{mg} \mathrm{AO}$ was diluted in $20 \mathrm{~mL}$ of $25 \mathrm{mM}$ sodium phosphate buffer with $\mathrm{pH}$ 7.0, and incubated for five minutes at $4 \stackrel{\circ}{ } \mathrm{C}$ with $1 \mathrm{~g}$ of $\mathrm{CNBr}$ support $\left(\mathrm{CNBr} \_\mathrm{AO}\right)$. Then, 10 $\mathrm{mL}$ of $1 \mathrm{M}$ ethanolamine with $\mathrm{pH} 8.0$ was added and the sample was stirred for 90 minutes, in order to block support groups that had not reacted with the enzyme (Valpato et al., 2009). The resulting biocatalyst was filtered, washed, and dried by suction. It was stored at 4 으 until use. The immobilization yield (\%) was calculated as $100 \times\left(a_{0}\right.$ $-a) / a_{0}$, where $a_{0}$ is the initial enzyme activity, and $a$ is the enzyme activity after immobilization. For this calculation, a mass of $0.1 \mathrm{~g}$ of derivative was resuspended in 1 $\mathrm{mL}$ of $50 \mathrm{mM}$ phosphate buffer at $\mathrm{pH} 7.0$.

\subsection{Amine Oxidase Immobilization by Multipoint Covalent Attachment on Glyoxyl-} Agarose Supports in the Presence of Polyethylene Glycol

Amine oxidase immobilization was oriented by the amino-terminal end as reported in the literature (Garcia-Garcia et al., 2019). All derivatives have the same load of AO (2.5mg 
$\mathrm{AO} / \mathrm{g}$ support).

The soluble enzyme was incubated in the presence of different percentages of polyethylene glycol $(0 \%, 10 \%, 20 \%, 30 \%, 40 \%$ and $50 \%)$ in $20 \mathrm{~mL}$ of $50 \mathrm{mM} \mathrm{pH} 8.5$ sodium phosphate buffer. Immobilization was performed at room temperature by adding one gram of glyoxyl-agarose6BCLsupport.

After immobilization, the immobilized enzyme was incubated at pH 10.0 in $30 \mathrm{~mL}$ of 100 $\mathrm{mM}$ sodium bicarbonate buffer for different times (3, 6 and 22 hours), in order to provide multipoint attachment by lysine residues located near the $\mathrm{N}$-terminus of the enzyme. At the end of the enzyme-support reaction, $1 \mathrm{mg} / \mathrm{mL}$ of sodium borohydride was added to the mixture at room temperature under vigorous stirring. After 30 minutes, it was vacuum filtered, washed with distilled water, and dried by suction. It was stored at 4 으 until use.

Furthermore, different derivatives with maximum enzymatic capacities were prepared by adding $200 \mathrm{mg}$ of $\mathrm{AO}$ per gram of glyoxyl-agarose $10 \mathrm{BCL}$ support, following the previously described protocol. The yield and recovered activity after the immobilization process were calculated in the same way as for one-point immobilization (see section 2.5).

\subsection{Inactivation of Immobilized Derivatives}

A total of $0.2 \mathrm{~g}$ of each biocatalyst was suspended in $2 \mathrm{~mL}$ of $50 \mathrm{mM}$ acetate buffer with $\mathrm{pH} 4.0$ (ratio $1: 10 \mathrm{w} / \mathrm{v}$ ) and $30 \%$ ethanol, and were incubated at $40{ }^{\circ} \mathrm{C}$. Each sample was analyzed at different times by measuring its enzymatic activity as described above. Residual activity was calculated as the ratio between the activity at a given time and the activity at the beginning of incubation. Half-life times (time in which the residual enzyme activity is half of its initial value) were calculated as previously described in the literature (Romero et al., 2012). Stabilization factors were determined by comparing half-life times 
of different derivatives and a reference; AO from Pisum sativum immobilized on the CNBr support, which behaves as a soluble enzyme (Bolivar et al., 2012).

\section{Results}

\subsection{Qualitative Evaluation of Amine Oxidase Aggregates}

The results of the DLS analysis are presented in Figure 1. Amine oxidase dissolved in buffer (in the absence of PEG) showed a well-defined peak related to monodisperse solutions. Moreover, $\mathrm{AO}$ dissolved in the presence of $10 \% \mathrm{PEG}$ exhibits a very small displacement of the main peak. However, AO dissolved in $30 \%$ of PEG exhibits a very clear displacement of a welldefined peak suggesting the formation of soluble molecular AO aggregates. The apparent increase in the particle size is 10 -fold higher with respect to AO without PEG. This huge difference could be a consequence of the increase in viscosity as well as the different solvation layers of the aggregates (Taraban et al, 2017). Finally, AO solution prepared with $50 \%$ PEG could not be studied as the size of the aggregates were over the scale of measurement for the equipmentused (more than $1000 \mathrm{kDa}$ ).

Consequently, results obtained from the DLS analysis expressed the distinct formation of aggregates in the presence of different amounts of PEG. In each case, $10 \%$ of PEG hardly promoted aggregation, while $30 \%$ of PEG promoted the formation of soluble molecular aggregates (around 2-4 molecules per aggregate) and 50\% PEG seemed to promote a very large macromolecular aggregation.

\subsection{Immobilization of Amine oxidase Aggregates by Amino-termini Orientation on Glyoxyl-Agarose Solid Supports}

The reaction between each amine group of the enzyme and each aldehyde group of the support creates a very unstable Schiff's base. That is why one-point covalent attachment is impossible. Consequently, enzyme immobilization on glyoxyl-agarose supports at $\mathrm{pH} 8.5$ (where only amino terminal ends of the enzyme are reactive) can only occur if attachment is developed simultaneously through two amino terminal ends of the enzyme and two aldehyde 
groups of the support.

Despite the fact that this complex immobilization protocol is very effective for the stabilization of enzymes, the number of amino terminal ends and their relative distance play a relevant role on the formation of thefirst simultaneous two-point enzyme-support attachment.

Both amino terminus of the isolated amine oxidase enzyme are placed in the same hemisphere but are far away from each other (see scheme 2). This is the reason why immobilization at pH 8.5 of the isolated enzyme had poor immobilization kinetics (Figure 2). Only $20 \%$ of the enzyme was immobilized after two hours of incubation with glyoxyl-agarose 6BCL support.

However, the kinetics of immobilization was highly increased when aggregation in the presence of PEG occurred. When using 30\% PEG, the immobilization rate was 600 -fold higher than that of the isolated enzyme, obtaining an immobilization yield of $100 \%$ in less than 20 minutes of reaction. This result indicates that amino terminal ends of the amine oxidase aggregate detected by DLS were also located on the same plane but also very close between them, allowing much more rapid two-point attachment. This dramatic increase in immobilization rate strongly suggest that the first two-point attachment of the molecular aggregate should involve two amino terminal residues belonging to different enzymes molecules of the molecular aggregate and being now closer than two amino terminal residues of each individual enzyme. In this way, this multipoint immobilization (at pH 8.5) also becomes a multi-enzyme molecule immobilization. At least, a bimolecular aggregate is "captured" via this immobilization protocol. If two-point would occur through two amino terminal residues of the same AO molecule, the immobilization rate would be very slow and similar to the one of the isolated AO molecule

Above $30 \%$ PEG, the immobilization rate decreased due to macromolecular aggregate formation. These higher aggregates possibly had the amino termini on the same plane but could not penetrate to the inner part of the glyoxyl-agarose 6BCL support, as described in the next section. 


\subsection{Quantitative Determination of Amine Oxidase Aggregates}

In order to determine the accurate size of the amine oxidase aggregates, immobilization of $\mathrm{AO}$ in the presence of three percentages of PEG $(10 \%, 30 \%$ and $50 \%)$ using $10 \mathrm{BCL}$ glyoxyl-agarose supports was studied.

Agarose $10 \mathrm{BCL}$ supports have a lower pore size than $6 \mathrm{BCL}$ supports, with an exclusion limit of $500 \mathrm{kDa}$. In this way, only enzymes with a fairly low MW will be able to completely load the internal surface of this support (around $200 \mathrm{mg}$ of a medium sized enzyme) (Mateo et al., 2006).

As it can be seen in Table 1, aggregates of $A O$ in the presence of $30 \%$ PEG were successfully immobilized on $10 B C L$ glyoxyl-agarose supports ( $91 \%$ of the enzyme was immobilized after 22 hours of incubation). However, AO aggregates with 50\% PEG only reached $10 \%$ immobilization at the same time of the study. In the same way, immobilization using AO in $10 \%$ PEG had slower immobilization kinetics.

Taking into account the molecular weight of AO (67 kDa per subunit), the possible formation of bi-molecular aggregates in the presence of 30\% PEG resulted in aggregates of $268 \mathrm{kDa}$. As the exclusion limit of glyoxyl-agarose $10 \mathrm{BCL}$ porous supports is $500 \mathrm{kDa}$, these aggregates can easily penetrate into the whole inner part of the support, resulting in rapid immobilization with full enzyme loading (Mateo et al., 2006). Aggregates formed at high percentages of PEG (50\%) have a very high molecular weight (more than 1000 $\mathrm{kDa}$ ) corresponding to poly-molecular aggregates. The size of these new compounds prevents their entry into the support, justifying the low kinetics of immobilization and the very low enzyme loading. On the other hand, $A O$ in the presence of $10 \%$ PEG weakly promotes aggregate formation. Although these molecules could easily penetrate $10 \mathrm{BCL}$ 
supports, they are not close enough to develop the immobilization via amino-termini orientation. In this case, only aggregates with a close proximity between amino-terminal ends of each aggregate could be immobilized on glyoxyl-agarose supports, either $6 \mathrm{BCL}$ or $10 \mathrm{BCL}$ supports.

Therefore, studying the maximum capacity for amine oxidase immobilization on glyoxylagarose $10 \mathrm{BCL}$ supports, the characterization of aggregates of different sizes was completed.

\subsection{Effect of Enzyme-support Interaction under Alkaline Conditions of Immobilized AO}

\section{Aggregates}

After immobilization of the enzyme aggregates at $\mathrm{pH} 8.5$ and $30 \% \mathrm{PEG}$, the immobilized derivative, attached through the amino termini, was long-term incubated at a basic $\mathrm{pH}$ $(\mathrm{pH} 10.0)$ in the absence of PEG. At this $\mathrm{pH}$, the additional attachment of Lys residues that are placed in the proximity of the amino-termini ends to glyoxyl groups on the support surface is favored.

The recovered activity of biocatalysts after incubation at $\mathrm{pH} 10.0$ for different times $(3,6$ and 22 hours) was studied(Table 2). Results were comparedwitha similarderivative of the isolated enzyme, immobilized at $\mathrm{pH} 8.5$ and incubated at $\mathrm{pH} 10$.

As it can be seen in Table 2, the loss of activity of the isolated immobilized enzyme is very relevant: it only retained $35 \%$ of its activity after 3 hours of interaction at $\mathrm{pH} 10$ and it decreased to $25 \%$ after 22 hours. It was previously reported in the literature that the additional interaction between the enzyme and support at $\mathrm{pH} 10$ generates new enzyme-support linkages that are related to the loss of activity in multimeric mesophilic enzymes (Garcia-Garcia et al., 2019).

On the contrary, the effect of interaction under alkaline conditions between the two aggregated molecules did not strongly affect the activity. Aggregates are critical at reducing 
distortions of both molecules promoted by an intense multipoint attachment resulting in a slight decrease of activity. In this case, the loss of activity of the immobilized aggregate is much lower; it retains $60 \%$ of its activity after 3 hours of incubation and $45 \%$ activity after 22 hours.

It seems that aggregation was preserved even after complete removal of PEG while incubating at $\mathrm{pH}$ 10. Otherwise, if the two molecules of the aggregated derivative were not interacting, both derivatives should have behaved identically.

\subsection{Additional Stabilization of Immobilized AO Aggregates by Multipoint Covalent Attachment under AlkalineConditions}

Finally, differences in time of interaction under alkaline conditions of the aggregated derivatives were studied in the same inactivation assay ( $\mathrm{pH} 4.0,30 \%$ ethanol and 40 으). These experimental conditions are similar to the ones where amine oxidase biocatalyst is used for the degradation of biogenic amines in wine.

According to the results shown in Figure 3, the most stable biocatalyst is the one that was incubated for 3 hours at $\mathrm{pH}$ 10.0. This derivative has a half-life time of almost 170 hours in the conditions described above. In this way, this derivative is 200 -fold times more stable than the $\mathrm{CNBr}-\mathrm{AO}$ derivative. Results were compared to $\mathrm{CNBr}-\mathrm{AO}$ as it behaves in a similar manner to that of the soluble enzyme (Valpato et al., 2009) avoiding undesirable aggregation problems. On the other hand, as represented in Figure 3, derivatives without further incubation at $\mathrm{pH} 10.0$ after immobilization or derivatives with long incubation periods at pH 10.0 (22 hours) were much less stable, with a halflife time of only 24 hours. Therefore, incubation time at a basic $\mathrm{pH}$ plays a decisive role on the stabilization of the enzyme. It is strictly necessary in order to stabilize the enzyme, but only a short incubation is highly positive. It was also demonstrated that, for multimeric mesophilic enzymes, intense multipoint attachment results in an important distortion of the enzymatic structure, leading to a negative effect on activity and stability (Garcia-Garcia et al., 2019; Trobo-Maseda et al., 2018). 
A comparison of $\mathrm{AO}$ derivatives immobilized by the $\mathrm{N}$-terminus in the presence and absence of polyethylene glycol, and incubated for 3 hours at $\mathrm{pH} 10.0$ were analyzed under the same conditions described before ( $\mathrm{pH} 4.0,40{ }^{\circ} \mathrm{C}$, in the presence of $30 \%$ ethanol). Figure 4 represents the inactivation of the isolated enzyme (immobilized in the absence of PEG) as well as the one of the aggregated enzyme (immobilized in the presence of PEG). While the stabilization factor of amine oxidase derivatives immobilized in the absence of PEG was about five times compared with the CNBr-AO derivative, the amine oxidase derivatives proposed in this study achieved a stabilization factor of 200 times in comparison with the native enzyme. That is, the immobilized aggregate enzyme was 40fold times more stable than the immobilized isolated enzyme. Again, the two enzyme molecules, aggregated in the presence of PEG, remained aggregated by joint covalent immobilization after removing PEG. This aggregation was preserved during multipoint attachment at $\mathrm{pH} 10$ and during thermal inactivation. However, both derivatives should exhibit identical behavior. Interestingly, the stabilizing effect of this aggregation (captured via immobilization techniques) could be evaluated: a 40 -fold stabilization by a bi-molecular aggregation was promoted. Therefore, the aggregated enzyme could be "captured" and the stabilization by aggregation became fascinating.

\section{Conclusions}

DLS studies demonstrated the aggregation of amine oxidase in the presence of PEG. At 30\% PEG, a well-defined molecular aggregate was formed. $200 \mathrm{mg}$ of this molecular aggregate were able to fully coat the internal surface of a mesoporous support: $10 \%$ agarose gel with an exclusion limit of $500 \mathrm{kDa}$. In this way, 30\% PEG should promote the formation of a bimolecular AO aggregate of $268 \mathrm{kDa}$ able to easily penetrate inside the porous structure of the mesoporous support.

Immobilization at pH 8.5 of this bi-molecular aggregate on glyoxyl-agarose was very fast 
(600 fold faster than immobilization of an isolated AO molecule) and it firstly occurred through simultaneous two-point attachment of two amino terminuses that belong to different molecules of the bi-molecular aggregate. Hence, the bimolecular aggregate became "captured" by immobilization. The two molecules of the aggregate remained in close contact and fixed on the support surface. Both enzyme molecules immobilized by multipoint attachment cannot undergo any relative movement (translational, rotational, etc.) and the aggregate cannotbe disaggregated.

The derivative obtained by multipoint attachment of the bi-molecular aggregate was 40 times more stable than a similar derivative of the isolated enzyme. The multipoint attachment should be similar in both cases and enzyme aggregation seemed to exert a very interesting stabilizing effect. This stabilizing effect of enzyme aggregation can be explained as follows: two aggregated enzyme molecules "captured" on a solid support are in close contact through large-side regions of their surfaces. In this way, conformational changes promoted in eachmolecule during thermal inactivation should be greatly restricted. The effect of aggregation plus multipoint attachment is additive and the immobilized derivative of the bi-molecular aggregate was 200 fold more stable than the native isolated enzyme.

Finally, Table 3 represents a summary of the positive effects obtained by the development of this novel procedure for the multipoint immobilization of bimolecular aggregates: multipoint immobilization through the amino termini of both enzyme molecules plus additional mild multi-interaction through Lys residues placed in the proximity of the amino termini.

Autor statement

Paz Garcia-Garcia has made the main experimental work Gloria Fernandez-Lorente has discussed the experiments 
Jose M. Guisan has discussed the experiments and has written the paper

\section{Declaration of interests}

The authors declare that they have no known competing financial interests or personal relationships that could have appeared to influence the work reported in this paper.

\section{References}

Bolivar, J.M., Rocha-martín, J., Mateo, C., Guisan, J.M., 2012. Stabilization of a highly active but unstable alcohol dehydrogenase from yeast using immobilization and post-immobilization techniques. Process Biochem. 47, 679-686. https://doi.org/10.1016/j.procbio.2012.01.012

Callejón, S., Sendra, R., Ferrer, S., Pardo, I., 2016. Cloning and characterization of a new laccase from Lactobacillus plantarum J16 CECT 8944 catalyzing biogenic amines degradation. Appl. Microbiol. Biotechnol. 100, 3113-3124. https://doi.org/10.1007/s00253-015-7158-0

Fernandez-Lafuente, R., Rodriguez, V., Mateo, C., Fernandez-Lorente, G., Arminsen, P., Sabuquillo, P., Guisan, J.M., 1999. Stabilization of enzymes (D-amino acid oxidase) against hydrogen peroxide via immobilization and post-immobilization techniques. J. Mol. Catal. B Enzym. 7, 173-179.

Fernandez-Lorente, G., Lopez-Gallego, F., M. Bolivar, J., Rocha-Martin, J., Moreno-Perez, S., M. Guisan, J., 2015. Immobilization of Proteins on Glyoxyl Activated Supports: Dramatic Stabilization of Enzymes by Multipoint Covalent Attachment on PreExisting Supports. Curr. Org. Chem. 19, 1-13. https://doi.org/10.2174/1385272819666150429232725

Garcia-Galan, C., Berenguer-Murcia, Á., Fernandez-Lafuente, R., Rodrigues, R.C., 2011. Potential of different enzyme immobilization strategies to improve enzyme performance. Adv. Synth. Catal. 353, 2885-2904. https://doi.org/10.1002/adsc.201100534 
Garcia-Garcia, P., Guisan, J.M., Fernandez-Lorente, G., 2019. Stabilization of multimeric enzymes by controlled multipoint covalent immobilization. J. Mol. Catal. A Chem. Manuscript submitted for publication.

García-Ruiz, A., González-Rompinelli, E.M., Bartolomé, B., Moreno-Arribas, M.V., 2011. Potential of wine-associated lactic acid bacteria to degrade biogenic amines. Int. J. Food Microbiol. 148, 115-120. https://doi.org/10.1016/j.ijfoodmicro.2011.05.009

Guisan, J.M., 2013. New Opportunities for Immobilization of Enzymes, in: Guisan, J.M. (Ed.), Immobilization of Enzymes and Cells. pp. 1-14. https://doi.org/10.1007/978$1-62703-550-7$

Guisan, J.M., 1988. Aldehyde-agarose gels as activated supports for immobilizationstabilization of enzymes. Enzyme Microb. Technol. 10, 375-382. https://doi.org/10.1016/0141-0229(88)90018-X

H. Orrego, A., Romero-Fernández, M., Millán-Linares, M., Yust, M., Guisán, J., RochaMartin, J., 2018. Stabilization of Enzymes by Multipoint Covalent Attachment on Aldehyde-Supports: 2-Picoline Borane as an Alternative Reducing Agent. Catalysts. https://doi.org/10.3390/catal8080333

Jemli, S., Ayadi-Zouari, D., Hlima, H. Ben, Bejar, S., 2016. Biocatalysts: Application and engineering for industrial purposes. Crit. Rev. Biotechnol. 36, 246-258. https://doi.org/10.3109/07388551.2014.950550

Kim, Y.J., Kim, Y.W., 2016. Optimizing the preparation conditions and characterization of cross-linked enzyme aggregates of a monoamine oxidase. Food Sci. Biotechnol. 25, 1421-1425. https://doi.org/10.1007/s10068-016-0221-5

Mateo, C., Abian, O., Bernedo, M., Cuenca, E., Fuentes, M., Fernandez-Lorente, G., Palomo, J.M., Grazu, V., Pessela, B.C.C., Giacomini, C., Irazoqui, G., Villarino, A., 
Ovsejevi, K., Batista-Viera, F., Fernandez-Lafuente, R., Guisán, J.M., 2005. Some special features of glyoxyl supports to immobilize proteins. Enzyme Microb. Technol. 37, 456-462. https://doi.org/10.1016/j.enzmictec.2005.03.020

Mateo, C., Palomo, J.M., Fernandez-Lorente, G., Guisan, J.M., Fernandez-Lafuente, R., 2007. Improvement of enzyme activity, stability and selectivity via immobilization techniques. Enzyme Microb. Technol. 40, 1451-1463. https://doi.org/10.1016/j.enzmictec.2007.01.018

Mateo, C., Palomo, J.M., Fuentes, M., Betancor, L., Grazu, V., López-Gallego, F., Pessela, B.C.C., Hidalgo, A., Fernández-Lorente, G., Fernández-Lafuente, R., Guisán, J.M., 2006. Glyoxyl agarose: A fully inert and hydrophilic support for immobilization and high stabilization of proteins. Enzyme Microb. Technol. 39, 274-280. https://doi.org/10.1016/j.enzmictec.2005.10.014

Mateo, C., Palomo, J.M., Van Langen, L.M., Van Rantwijk, F., Sheldon, R.A., 2004. A New, Mild Cross-Linking Methodology to Prepare Cross-Linked Enzyme Aggregates. Biotechnol. Bioeng. 86, 273-276. https://doi.org/10.1002/bit.20033

McGuirl, M. a, McCahon, C.D., McKeown, K. a, Dooley, D.M., 1994. Purification and characterization of pea seedling amine oxidase for crystallization studies. Plant Physiol. 106, 1205-11. https://doi.org/10.1104/pp.106.3.1205

Moreno-Pérez, S., Orrego, A.H., Romero-Fernández, M., Trobo-Maseda, L., MartinsDeoliveira, S., Munilla, R., Fernández-Lorente, G., Guisan, J.M., 2016. Intense PEGylation of Enzyme Surfaces: Relevant Stabilizing Effects. Methods Enzymol. 571, 55-72. https://doi.org/10.1016/bs.mie.2016.02.016

Prasad, S., Roy, I., 2017. Converting Enzymes into Tools of Industrial Importance. Recent Pat. Biotechnol.

12 $33-56$. 
Romero, O., Manuel, J., Illanes, A., Wilson, L., 2012. Reactivation of penicillin acylase biocatalysts : Effect of the intensity of enzyme - support attachment and enzyme load. J. Mol. Catal. B. Enzym. 74, 224-229. https://doi.org/10.1016/j.molcatb.2011.10.009

Sheldon, R.A., 2011. Characteristic features and biotechnological applications of crosslinked enzyme aggregates (CLEAs). Appl. Microbiol. Biotechnol. 92, 467-477. https://doi.org/10.1007/s00253-011-3554-2

Singh, R.K., Tiwari, M.K., Singh, R., Lee, J.K., 2013. From protein engineering to immobilization: Promising strategies for the upgrade of industrial enzymes. Int. J. Mol. Sci. 14, 1232-1277. https://doi.org/10.3390/ijms14011232

Taraban, M.B., Depaz, R.A., Lobo, B., Yu, Y.B. Water Proton NMR: A Tool for Protein Aggregation Characterization (2017) Analytical Chemistry, 89 (10), pp. 5494-5502.

Terrasan, C.R.F., Aragon, C.C., Masui, D.C., Pessela, B.C., Fernandez-Lorente, G., Carmona, E.C., Guisan, J.M., 2016. $\beta$-xylosidase from Selenomonas ruminantium: Immobilization, stabilization, and application for xylooligosaccharide hydrolysis. Biocatal. Biotransformation 34, 161-171. https://doi.org/10.1080/10242422.2016.1247817

Trobo-Maseda, L., Orrego, A.H., Moreno-Pérez, S., Fernández-Lorente, G., Guisan, J.M., Rocha-Martin, J., 2018. Stabilization of multimeric sucrose synthase from Acidithiobacillus caldus via immobilization and post-immobilization techniques for synthesis of UDP-glucose. Appl. Microbiol. Biotechnol. 102, 773-787. https://doi.org/10.1007/s00253-017-8649-y

Volpato, G., Filice, M., Rodrigues, R.C., Heck, J.X., Guisan, J.M., Mateo, C., Ayub, M.A.Z. Modulation of a lipase from Staphylococcus warneri EX17 using immobilization techniques (2009) Journal of Molecular Catalysis B: Enzymatic, 60 (3-4), pp. 125-132. 
Wilson, L., Betancor, L., Fernández-Lorente, G., Fuentes, M., Hidalgo, A., Guisán, J.M., Pessela, B.C.C., Fernández-Lafuente, R., 2004. Cross-linked aggregates of multimeric enzymes: A simple and efficient methodology to stabilize their quaternary structure. Biomacromolecules $\quad 5, \quad 814-817$. https://doi.org/10.1021/bm034528i

Yagodina, O. V., Nikol'skaya, E.B., Khovanskikh, A.E., Kormilitsyn, B.N., 2002. Amine oxidases of microorganisms. J. Evol. Biochem. Physiol. 38, 251-258. https://doi.org/10.1023/A:1020714607203 
Scheme 1. - 3D-structure of Pisum sativum amine oxidase. Amino-terminus residues (Green). Lysine residues (Blue).
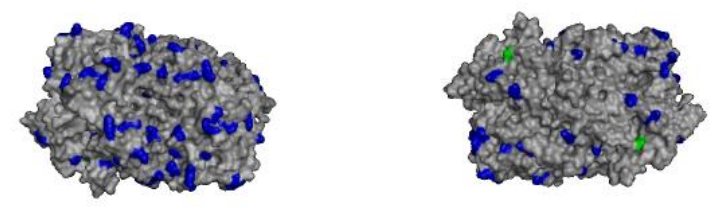

Scheme 2.- Schematic representation of immobilization of $\mathrm{AO}$ at $\mathrm{pH} 8.5$ (through the amino terminus). A: immobilization of the isolated enzyme; $B$. immobilization of a bimolecular aggregate.

Two-point immobilization

through 2 amino terminus of an isolated $\mathrm{AO}$ molecule

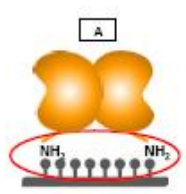

Scheme 2
Multi-point immobilization

through 4 amino terminus

of a bimolecular aggregate

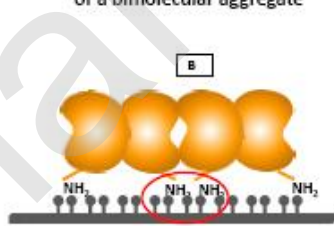

Figure 1. - Qualitative evaluation of AO aggregates by Dynamic Light Scattering in the absence or presence of polyethyleneglycol. Experiments were performed as described in Methods. The relative size of the aggregates is not exact because of the influence of viscosity, solvation layers, etc. Closed circles: $A O$ in the absence of PEG; Closed squares: $\mathrm{AO}$ in the presence of $10 \% \mathrm{PEG}$; Closed triangles: $\mathrm{AO}$ in the presence of $30 \% \mathrm{PEG}$. 


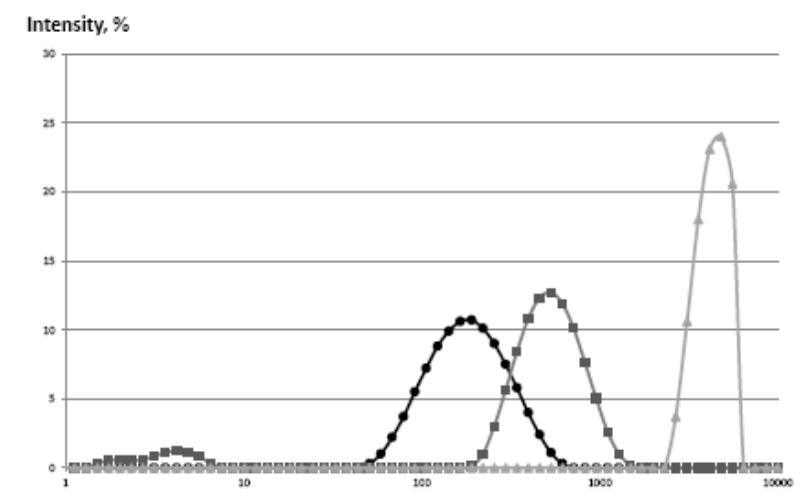

Figure 1

Hydrodynamic size, $\mathrm{nm}$

Figure 2. - Time-course of inactivation of different AO derivatives in the presence of $30 \%$ of ethanol, at $\mathrm{pH} 4.0$ and $40^{\circ} \mathrm{C}$. Closed rhombus: $\mathrm{CNBr}$ immobilized $\mathrm{AO}$ (one-point covalent immobilization of the isolated enzyme); Open circles: aggregated $\mathrm{AO}$ ( $30 \% \mathrm{PEG}$ ) incubated 3 hours at $\mathrm{pH} 10$ after immobilization at pH 8.5. Closed triangles: aggregated $\mathrm{AO}(30 \% \mathrm{PEG})$ incubated 6 hours at $\mathrm{pH} 10$ after immobilization at $\mathrm{pH} 8.5$; Closed squares: aggregated $\mathrm{AO}$ (30\% PEG) incubated 22 hours at $\mathrm{pH} 10$ after immobilization at $\mathrm{pH}$ 8.5; Asterisks: aggregated $\mathrm{AO}(30 \% \mathrm{PEG})$ immobilized at $\mathrm{pH} 8.5$ and with no incubation at $\mathrm{pH}$ 10.

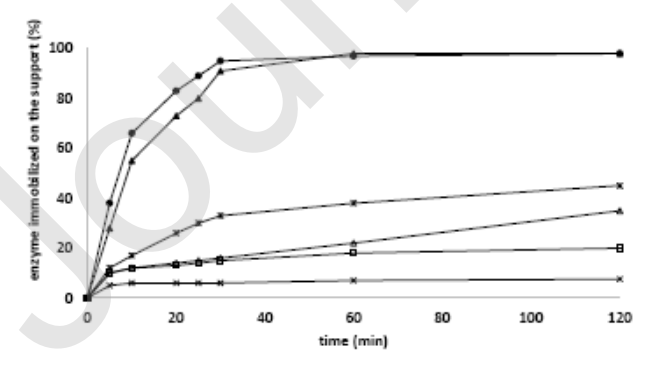

Figure 2

Figure 3. - Time-course of inactivation of different AO derivatives in the presence of $30 \%$ of ethanol, at $\mathrm{pH} 4.0$ and $40^{\circ} \mathrm{C}$. Experiments were carried out as described in Methods: Asterisks: $\mathrm{CNBr}$ - immobilized AO (one-point covalent immobilization of the isolated enzyme); Closed circles: aggregated AO (30\% PEG) incubated 3 hours at pH 10 
after immobilization at $\mathrm{pH} 8.5$; Closed squares: isolated $\mathrm{AO}$ incubated 3 hours at $\mathrm{pH} 10$ after immobilization at $\mathrm{pH} 8.5$.

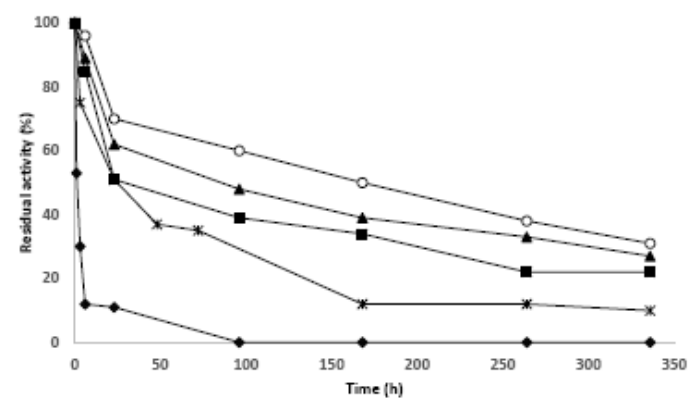

Figure 3

Figure 4

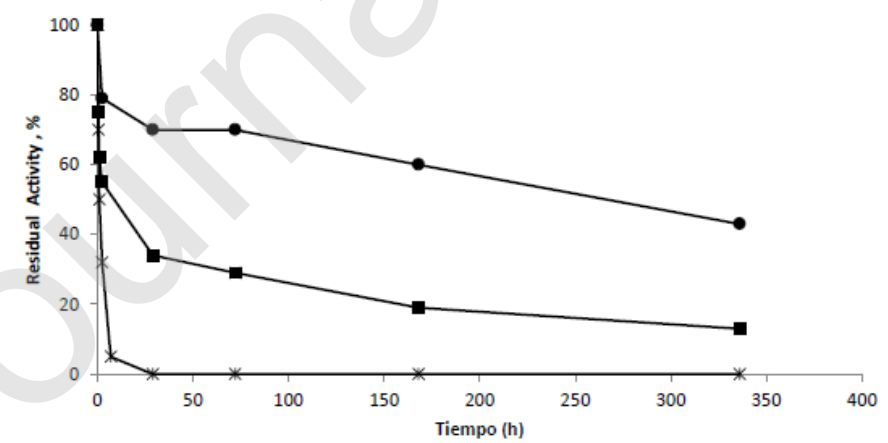

Figure 4 
Table 1. - Immobilization of AO P. sativum on glyoxyl-agarose $10 \mathrm{BCL}$ in the presence of different percentages of PEG.

\begin{tabular}{lccc}
\hline \multicolumn{4}{c}{ Immobilization (\%) } \\
\hline Time (h) ${ }^{\text {a }}$ & 10\%PEG & 30\%PEG & 50\%PEG \\
\hline $\mathbf{1}$ & 5 & 9 & 3 \\
\hline $\mathbf{1 . 5}$ & 10 & 16 & 10 \\
\hline $\mathbf{2 2}$ & 95 & & \\
\hline \% of enzyme immobilized at different times. Enzyme offered to the support: 200 mg of pure \\
enzyme per gram of glyoxyl-agarose. The support was $10 \%$ glyoxyl-agarose with an exclusion \\
limit for proteins of $500 \mathrm{kDa}$.
\end{tabular}

Table 2. - Effect of incubation at pH 10 in the recovered activity of glyoxyl AO derivatives.

\begin{tabular}{ccc}
\hline Time (h) a & Without PEG & 30\% PEG \\
\hline 3 & 36 & 57 \\
\hline 6 & 34 & 51 \\
\hline 22 & 25 & 45
\end{tabular}

${ }^{\mathrm{a}}$ Incubation times at $\mathrm{pH} 10$ of $\mathrm{AO}$ immobilized at $\mathrm{pH} 8.5$.

${ }^{\mathrm{b}}$ Recovered activity of different glyoxyl- $\mathrm{AO}$ derivatives. Expressed as the percentage of activity regarding the enzyme used for the immobilization at $\mathrm{pH} 8.5$ 
Table 3. - Improvement of immobilization parameters by aggregation vs. isolated AO. The immobilization protocol "captures" the bi-molecular aggregate and aggregation promotes a very interesting stabilization.

Parameter

Immobilization rate

Recovered activityafter immobilization

Stabilization of immobilized derivatives
Factor of improvement

$X 600$

$\times 2$

$X 40$ 